\title{
Alpha-2 Adrenoceptors Modulate the Somatostatinergic System and G Protein Levels in the Rat Hippocampus
}

Susana López-Sañudo, Ph.D., Lilian Puebla, B.Sc., Luis G. Guijarro, Ph.D., Juan C. Prieto, Ph.D., and Eduardo Arilla, M.D.

$\alpha_{2}$-Adrenoceptor agonists and somatostatin (SS) exert opposite effects on the spike discharge of pyramidal and granule cells in the rat hippocampus. We studied whether clonidine, an a2-adrenoceptor agonist, and yohimbine, an $\alpha_{2}$-adrenoceptor antagonist, can modulate somatostatinlike immunoreactivity (SSLI) levels, binding of ${ }^{125} \mathrm{I}_{\text {-Tyr }}{ }^{11}$ somatostatin ( ${ }^{125}$ I-Tyr ${ }^{11}$-SS) to its specific receptors, SSinhibited adenylyl cyclase (AC) activity, and the guaninenucleotide binding regulatory proteins $G_{i}$ and $G_{0}$ in the rat hippocampus. Clonidine $(1 \mathrm{mg} / \mathrm{kg}$, intraperitoneally (IP) or yohimbine $(5 \mathrm{mg} / \mathrm{kg}, I P)$ injected at both 10 and 16 hours before decapitation did not affect SSLI content in the hippocampus. Clonidine administration decreased the number of specific SS receptors and increased the apparent affinity in hippocampal membranes. This change in SS binding was not the result of a direct effect of clonidine on these receptors because no effect in binding was produced by high concentrations of clonidine $\left(10^{-5} \mathrm{M}\right)$ when added in vitro. Pretreatment with yohimbine prevented the clonidine-induced in SS binding. Yohimbine alone produced a significant increase in the number of ${ }^{125 I-T y r^{11}-S S}$ receptors and a decrease in its apparent affinity. Clonidine decreased the ADPribosylation of a 41- and a 39-kDa G-protein by pertussis toxin (PTX), whereas yohimbine had no effect on the PTX-catalyzed ADP-ribosylation. No significant differences were seen for the basal or for the forskolin (FK)-stimulated AC enzyme activities in the control, clonidine- and/or yohimbine-treated groups. Somatostatin caused a significantly lower inhibition in AC activity in hippocampal membranes of clonidine-treated rats, whereas yohimbine led to an opposite effect. Pretreatment with yohimbine prevented the clonidine-induced changes in AC activity. These results support the existence of a significant interaction between $\alpha_{2}$-adrenoceptors and SS receptors in the rat hippocampus.

[Neuropsychopharmacology 12:47-55, 1995]
KEY WORDS: Clonidine-, Yohimbine-, Somatostatin receptors; Adenylyl cyclase; G proteins; Hippocampus

Noradrenaline (NA) and somatostatin (SS) are two important neurotransmitters that are widely distributed in the central nervous system (CNS) (Moore and Bloom

From the Facultad de Medicina, Universidad de Alcalá, Madrid, Spain.

Address correspondence to: Unidad de Neuroendocrinología Molecular, Departamento de Bioquímica y Biología Molecular, Facultad de Medicina, Universidad de Alcalá, E-28871, Alcalá de Henares, Madrid, Spain.

Received March 18, 1994; revised July 1, 1994; accepted August 3, 1994.
1979; Reichlin 1983; Epelbaum 1986). The major ascending NA tract from the locus coeruleus of the rat brain is the dorsal (tegmental) bundle, from which fibers innervate the cerebral cortex, thalamus, hippocampus, amygdala, and septum (Levitt and Moore 1978; Milner and Bacon 1989). In the hippocampus, immunohistochemical studies have revealed many SS-containing interneurons and a profuse network of intrinsic and extrinsic SS-containing fibers that appear to project to pyramidal and granule neurons (Bakst et al. 1986; Joëls et al. 1990). In addition, a dense colocalization of SS with NA has been observed in several brain areas, although is not constantly observed (Seroogy et 
al. 1989; Sakanaka et al. 1990). Specific high affinity receptors for both $\alpha_{2}$-adrenergic agonists (Bylund 1988; Wamsley et al. 1992; Alburges et al. 1993) and SS (Epelbaum et al. 1982; Palacios et al. 1986; Krantic et al. 1990) have been characterized, and there is strong evidence that these receptors mediate the biological effects of both neurotransmitters in the hippocampus. There is good evidence for the existence of SS receptors in the locus coeruleus (Epelbaum et al. 1990), a small homogenous cluster of NA-containing neurons located in the dorsolateral pontine tegmentum. Recently, a study by our group has suggested that a portion of the hippocampal SS receptors may be localized presynaptically on the noradrenergic nerve terminals (López-Sañudo and Arilla 1992).

Recent studies support the view that SS is predominantly an inhibitory transmitter in the hippocampus (Watson and Pittman 1988; Schweitzer et al. 1993), whereas selective agonists for the $\alpha_{2}$-adrenergic receptors excite the hippocampal interneurons and the pyramidal neurons (Pang and Rose 1987). Furthermore, SS produces opiate-like effects (Rezek et al. 1977) and $\alpha_{2}$-adrenergic antagonists, such as yohimbine, potentiated the opioid agonist effects (Jackisch et al. 1986). Therefore, it was of interest to determine whether the receptors for SS were modulated by the $\alpha_{2}$-adrenergic system. Thus, clonidine, an $\alpha_{2}$-adrenergic agonist, and yohimbine, an $\alpha_{2}$-adrenergic blocking agent, were utilized. Because the post-receptor mechanism of action of SS includes, at least in part, the inhibition of adenylyl cyclase (AC) activity following activation of SS receptors coupled via GTP binding "G proteins" to the enzyme (Nagao et al. 1989; Schettini et al. 1989; MurrayWhelan and Schlegel 1992), we studied SS-inhibited AC activity in hippocampal membranes from clonidine and/or yohimbine-treated rats. In addition, we measured the catalytic subunit of AC by means of stimulation with the diterpene forskolin (FK), and assessed the guanine-nucleotide regulatory proteins ( $G$ proteins) by experiments on pertussis toxin (PTX)-catalyzed ADPribosylation of hippocampal membranes. We extended our analysis to study possible effects of clonidine and/or yohimbine on hippocampal somatostatin-like immunoreactivity (SSLI) content.

\section{MATERIALS AND METHODS}

\section{Materials}

Synthetic Tyr ${ }^{11}$-somatostatin (Tyr ${ }^{11}$-SS) and SS tetradecapeptide were purchased from Universal Biologicals Ltd (Cambridge, U.K.); yohimbine hydrocholoride, clonidine hydrochloride, bacitracin, phenylmethylsulfonyl fluroide (PMSF), 3-isobutyl-1-methylxanthine
(IBMX), PTX, bovine serum albumin (BSA), GTP, FK, and prestained protein markers and other reagents for sodium dodecyl sulfate-polyacrylamide gel electrophoresis (SDS-PAGE) were supplied by Sigma Química (Madrid, Spain); and carrier-free Na ${ }^{125 I}$ (IMS 30, 100 $\mathrm{mCi} / \mathrm{ml}$ ) from the Radiochemical Centre (Amersham, U.K.). The rabbit antibody used in the radioimmunoassay technique was purchased from the Radiochemical Centre (Amersham, U.K.). This antiserum was raised in rabbits against SS-14 conjugated to BSA and is specific for SS, but because SS-14 also constitutes the C-terminal portions of both SS-25 and SS-28, the antiserum does not distinguish between these three forms. Crossreactivity with other peptides was less than $0.5 \%$. Crossreaction with several SS analogues demonstrated that neither the $\mathrm{N}$-terminal glycine nor the $\mathrm{C}$-terminal cysteine residue is required for antibody binding, suggesting that the antigen site is directed towards the central part of the molecule containing the tryptophan residue. The binding of SS-14 to its antibody does not depend on an intact disulfide bond in the molecule because breaking of the disulfide bond by reaction with $0.1 \%$ mercaptoethanol (boiling water bath, 5 minutes) did not change peptide immunoreactivity (Penman et al. 1979).

\section{Experimental Animals}

The animals used in this study were male Sprague Dawley rats $(n=60)$ weighing between 200 and $250 \mathrm{~g}$. Rats were maintained on a 12-hour light/dark cycle $(07.00$ to 19.00) and allowed free access to food. The rats were acclimated to the light/dark cycle from the moment of birth until they weighed 200 to $250 \mathrm{~g}$. Clonidine $(1 \mathrm{mg} / \mathrm{kg})$ and yohimbine $(5 \mathrm{mg} / \mathrm{kg})$ were dissolved in distilled water or saline, respectively, as previously described (Blaustein and Letcher 1987). Drug doses were selected according to the effective doses reported in previous studies (Blaustein and Letcher 1987). Fresh solutions were prepared every day just before the administration. Drugs were diluted such that injections were in volumes of $2.0 \mathrm{ml} / \mathrm{rat}$ and were administered intraperitoneally (IP) at both 10 and 16 hours prior to assay as previously described (Blaustein and Letcher 1987). In another experimental group, yohimbine $(5 \mathrm{mg} / \mathrm{kg}, \mathrm{IP})$ was administered 1 hour before clonidine $(1 \mathrm{mg} / \mathrm{kg}$, IP). Control injections were equivalent volumes of distilled water or saline. The rats were treated at $16.00 \mathrm{~h}$ and at 22.00 hours and were sacrificed at 9.00 hours of the following morning. Rats were killed by decapitation, the brain was rapidly removed, and the hippocampus was dissected over ice according to the method of Glowinski and Iversen (1966).

All procedures conform to guidelines set for our Animal Care and Use Committee and were approved by the Committee before implementation. 


\section{Tissue Extraction and SS Radioimmunoassay}

For SSLI measurements, the hippocampus was rapidly homogenized using a Brinkman polytron (setting 5, $30 \mathrm{~s}$ ), in $1 \mathrm{ml} 2 \mathrm{~mol} / \mathrm{L}$ acetic acid. Extracts were boiled for 5 minutes in a water bath, chilled in ice, and aliquots $(100 \mu \mathrm{l})$ were removed for protein determination (Lowry et al. 1951). Subsequently, homogenates were centrifuged at $15,000 \mathrm{~g}$ for 15 minutes at $4^{\circ} \mathrm{C}$, and the supernatant was neutralized with $2 \mathrm{~mol} / \mathrm{L} \mathrm{NaOH}$. Extracts were immediately stored at $-70^{\circ} \mathrm{C}$ until assay. Somatostatin-like immunoreactivity level was determined in tissue extracts by a modified radioimmunoassay method (Patel and Reichlin 1978), with a sensitivity limit of $10 \mathrm{pg} / \mathrm{ml}$. Incubation tubes prepared in duplicate contained $100 \mu \mathrm{l}$ samples of unknown or standard solutions of 0 to $500 \mathrm{pg}$ cyclic SS tetradecaptide diluted in phosphate buffer $(0.05 \mathrm{~mol} / \mathrm{L}, \mathrm{pH} 7.2$ containing $0.3 \%$ BSA, $0.01 \mathrm{M}$ EDTA), $200 \mu \mathrm{l}$ of appropriately diluted anti-serum, $100 \mu \mathrm{l}$ of freshly prepared ${ }^{125} \mathrm{I}^{-T_{y} \mathrm{r}^{11} \text {-SS }}$ diluted in buffer to give $6,000 \mathrm{cpm} /$ assay tube (equivalent to 5 to $10 \mathrm{pg}$ ), and enough buffer to give a final volume of $0.8 \mathrm{ml}$. All reagents as well as the assay tubes were kept chilled on ice before incubation at $4^{\circ} \mathrm{C}$ for 48 hours. Separation of bound and free hormone was accomplished by the addition of $1 \mathrm{ml}$ dextran-coated charcoal (dextran T70: 0.2\% w/v, Pharmacia, Uppsala, Sweden; charcoal: Norit A $2 \%$ w/v, Serva, Feinbiochemica, Heidelberg, Germany). Dilution curve for this brain area was parallel to the standard curve. The intra- and interassay variation coefficients were $6.8 \%$ and $8.1 \%$, respectively.

\section{Binding Assay}

Tyr ${ }^{11}$-SS was radioiodinated by chloramine-T iodination according to the method of Greenwood et al. (1963). Separation of iodinated SS from unincorporated iodine was performed on a Sephadex G-25 (fine) column equilibrated and eluted with $0.1 \mathrm{~mol} / \mathrm{L}$ acetic acid in BSA $(0.1 \% \mathrm{w} / \mathrm{v})$. The specific activity of the radioligand was $600 \mathrm{Ci} / \mathrm{mmol}$.

Hippocampal membranes were prepared as described by Reubi et al. (1981). Proteins were assayed by the method of Lowry et al. (1951), with BSA as a standard. Specific SS binding was measured according to the modified method of Czernik and Petrack (1983). The membranes $(0.15 \mathrm{mg}$ protein $/ \mathrm{ml})$ were incubated in $0.25 \mathrm{ml}$ of a medium containing $50 \mathrm{mmol} / \mathrm{L}$ Tris- $\mathrm{HCl}$ buffer $(\mathrm{pH}=7.5), 5 \mathrm{mmol} / \mathrm{L} \mathrm{MgCl}, 0.2 \%$ (w/v) BSA and $0.1 \mathrm{mg} / \mathrm{ml}$ bacitracin with $250 \mathrm{pmol} / \mathrm{L}$ ${ }^{125} \mathrm{I}$-Tyr ${ }^{11}$-SS either in the absence or in the presence of 0.01 to $10 \mathrm{nmol} / \mathrm{L}$ unlabeled SS. After 60 minutes incubation at $30^{\circ} \mathrm{C}$, membrane-bound peptide was isolated by centrifugation at $11,000 \mathrm{~g}$ for 2 minutes, and radioactivity was determined in a Kontron gamma counter.
Nonspecific binding was obtained from the amount of radioactivity bound in the presence of $10^{-7} \mathrm{~mol} / \mathrm{L} \mathrm{SS}$ and represented approximately $20 \%$ of the binding observed in the absence of unlabeled peptide. This nonspecific component was subtracted from the total bound radioactivity to obtain the corresponding specific binding.

\section{Evaluation of Radiolabeled Peptide Degradation}

To determine the extent of tracer degradation during incubation, we measured the ability of preincubated peptide to bind to fresh hippocampal membranes as previously described (Aguilera et al. 1982). Briefly, ${ }^{125} \mathrm{I}-$ $\mathrm{Tyr}^{11}$-SS (250 pmol/L) was incubated with membranes from rat hippocampus $(0.15 \mathrm{mg}$ protein $/ \mathrm{ml})$ for 60 minutes at $30^{\circ} \mathrm{C}$. After this preincubation, aliquots of the medium were added to fresh membranes and incubated for an additional 60 minutes at $30^{\circ} \mathrm{C}$. The fraction of the added radiolabeled peptide that was specifi-cally bound during the second incubation was measured and expressed as a percentage of the binding that had been obtained in control experiments performed in the absence of membranes during the preincubation period.

\section{Adenylyl Cyclase Assay}

Adenylyl cyclase activity was measured as previously reported (Houslay et al. 1976) with minor modifications (Guijarro et al. 1992). Briefly, rat hippocampal membranes $(0.06 \mathrm{mg} / \mathrm{ml})$ were incubated with $1.5 \mathrm{mmol} / \mathrm{L}$ ATP, $5 \mathrm{mmol} / \mathrm{L} \mathrm{MgSO}_{4}, 10 \mu \mathrm{M} \mathrm{GTP}$, an ATP-regenerating system $(7.5 \mathrm{mg} / \mathrm{ml}$ creatine phosphate and 1 $\mathrm{mg} / \mathrm{ml}$ creatine kinase), $1 \mathrm{mmol} / \mathrm{L} \mathrm{IBMX}, 0.1 \mathrm{mM}$ PMSF, $1 \mathrm{mg} / \mathrm{ml}$ bacitracin, $1 \mathrm{mM}$ EDTA, and test substances $\left(10^{-4} \mathrm{~mol} / \mathrm{L} \mathrm{SS}\right.$ or $\left.10^{-5} \mathrm{~mol} / \mathrm{L} \mathrm{FK}\right)$ in $0.1 \mathrm{ml}$ of 0.025 $\mathrm{mol} / \mathrm{L}$ triethanolamine $/ \mathrm{HCl}$ buffer ( $\mathrm{pH} 7.4)$. After 15 minutes incubation at $30^{\circ} \mathrm{C}$, the reaction was stopped by heating the mixture for 3 minutes. After refrigeration, $0.2 \mathrm{ml}$ of an alumina slurry $(0.75 \mathrm{~g} / \mathrm{ml}$ in triethanolamine $/ \mathrm{HCl}$ buffer, $\mathrm{pH} 7.4$ ) was added, and the suspension was centrifuged. The supernatant was taken to assay the cyclic AMP (cAMP) by using the method of Gilman (1970). The SS concentration was the one that is known to inhibit rat (Nagao et al. 1989; Schettini et al. 1989) and human (Garlind et al. 1992) brain AC. Forskolin was used at a concentration of $10^{-5} \mathrm{~mol} / \mathrm{L}$, which primarily stimulates the catalytic subunit of AC (Seamon and Daly 1986).

\section{Pertussis Toxin-Catalyzed ADP-Ribosylation}

The PTX-catalyzed ADP-ribosylation was performed as previously reported (Bokoch et al. 1983). After PTX ac- 
tivation, membranes $(0.8 \mathrm{mg}$ of protein $/ \mathrm{ml})$ were incubated with PTX $(16 \mu \mathrm{g} / \mathrm{ml})$ in $100 \mathrm{mmol} / \mathrm{L}$ Tris $/ \mathrm{Cl}$ buffer ( $\mathrm{pH} \mathrm{8.0)}$ ), containing $10 \mathrm{mmol} / \mathrm{L}$ thymidine, 1 $\mathrm{mmol} / \mathrm{L}$ ATP, $100 \mu \mathrm{M}$ GTP, $2.5 \mathrm{mmol} / \mathrm{L} \mathrm{MgCl}_{2}, 1$ $\mathrm{mmol} / \mathrm{L}$ EDTA, $1 \mu \mathrm{mol} / \mathrm{L}\left[{ }^{32} \mathrm{P}\right] \mathrm{NAD}^{+}(30 \mathrm{Ci} / \mathrm{mmol})$ and an ATP-regenerating system. After 30 minutes at $30^{\circ} \mathrm{C}$, the reaction was stopped by addition of $1 \mathrm{ml}$ of ice-cold $100 \mathrm{mmol} / \mathrm{L}$ Tris/HCl buffer ( $\mathrm{pH} \mathrm{8.0)}$ ), sedimented by centrifugation for 10 minutes at $30,000 \mathrm{~g}$ solubilized with $0.1 \mathrm{ml}$ of $60 \mathrm{mmol} / \mathrm{L}-\mathrm{Tris} / \mathrm{HCl}$ buffer ( $\mathrm{pH} 6.8$ ) containing $10 \%$ glycerol, $0.001 \%$ bromophenol blue, and $3 \%$ SDS (SDS-sample buffer). After heating for 30 minutes at $60^{\circ} \mathrm{C}$, the suspension was centrifuged for 10 minutes at $100,000 \mathrm{~g}$, and aliquots of the supernatant were submitted to SDS-PAGE, using the procedure of Laemmli (1970) as previously described (Laburthe et al. 1984). The gels were run, fixed, dried, and exposed to Dupont films (cronex 4) for 1 to 7 days at $-80^{\circ} \mathrm{C}$, using an intensifying screen.

\section{Data Analysis}

The computer program LIGAND (Munson and Rodbard 1980) was used to analyze the binding data. The use of this program enabled models of receptors that best fit given sets of binding data to be selected. The same program was also used to present data in the form of Scatchard plots (Scatchard 1949) and to compute values for receptor affinity $(\mathrm{Kd})$ and density $(\mathrm{Bmax})$ that best fit the sets of binding data for each rat. Statistical comparisons of all the data were performed with one way analysis of variance (ANOVA) and the Student's Newman-Keuls test. Means among groups were considered significantly different when the $P$ value was less than 0.05 . Each individual experiment was performed in duplicate.
Table 1. Effect of Clonidine, Yohimbine, and Yohimbine plus Clonidine on Somatostatin-like Immunoreactive (SSLI) Concentration and Equilibrium Parameters for SS Binding to Hippocampal Membranes

\begin{tabular}{llcc}
\hline & \multicolumn{2}{c}{ SS Receptors } & \\
\cline { 2 - 3 } Group & \multicolumn{1}{c}{ Bmax } & Kd & SSLI \\
\hline Control & $518 \pm 19$ & $0.43 \pm 0.01$ & $9.44 \pm 0.84$ \\
Clonidine & $324 \pm 18^{a}$ & $0.20 \pm 0.02^{a}$ & $8.90 \pm 0.27$ \\
Control & $513 \pm 39$ & $0.31 \pm 0.04$ & $9.02 \pm 1.11$ \\
Yohimbine & $676 \pm 36^{b}$ & $0.53 \pm 0.03^{b}$ & $9.31 \pm 0.89$ \\
$\begin{array}{l}\text { Control } \\
\begin{array}{l}\text { Yohimbine } \\
\text { plus clonidine }\end{array}\end{array}$ & $499 \pm 25$ & $0.33 \pm 0.05$ & $9.84 \pm 0.50$ \\
\hline
\end{tabular}

Binding parameters were calculated from Scatchard plots by linear regression (Scatchard 1949). Units for SSLI are ng of SS per mg protein, units for $\mathrm{Kd}$ are $\mathrm{nmol} / \mathrm{L}$, and units for Bmax are femtomoles of SS bound per mg of protein. The results are represented as the mean \pm SEM of five separate experiments. Statistical comparison versus control: ${ }^{a} p<.001,{ }^{b} p<.01$.

\section{RESULTS}

Clonidine or yohimbine had no effect on the SSLI content in the hippocampus as compared with the control group (Table 1). Preliminary experiments confirmed that specific binding of ${ }^{125} \mathrm{I}_{-} \mathrm{Tyr}^{11}$-SS to hippocampal membranes changed linearly with protein concentration and was time-dependent in all experimental groups. An apparent equilibrium was observed between 50 and 180 minutes at $30^{\circ} \mathrm{C}$ (data not shown). All subsequent binding experiments were therefore conducted at $30^{\circ} \mathrm{C}$ for 60 minutes. Hippocampal membranes from control and clonidine- or yohimbine-treated rats showed a similar peptide degradation capacity, and the values varied by no more than $10 \%$ in all the experimental groups.
Figure 1. Scatchard plots of the specific binding of ${ }^{125} \mathrm{I}-\mathrm{Tyr}^{11}$ somatostatin ( ${ }^{125} \mathrm{I}-\mathrm{Tyr}^{11}$-SS) to hippocampal membranes from controls and the rats treated with clonidine (A), yohimbine (B), and yohimbine-plus-clonidine (C). Membranes $(0.15 \mathrm{mg}$ protein $/ \mathrm{ml})$ were incubated for 60 minutes at $30^{\circ} \mathrm{C}$ in the presence of $250 \mathrm{pmol} / \mathrm{L}$ ${ }^{125} \mathrm{I}-T y r^{11}$-SS and increasing concentrations of native peptide. Points correspond to controls $(\bullet)$, clonidine- $(O)$, yohimbine- $(\Delta)$, and yohimbine-plus-clonidine-treated rats $(\square)$. Values are expressed as the mean of five replicate experiments. The corresponding equilibrium binding parameters are included in Table 1 .

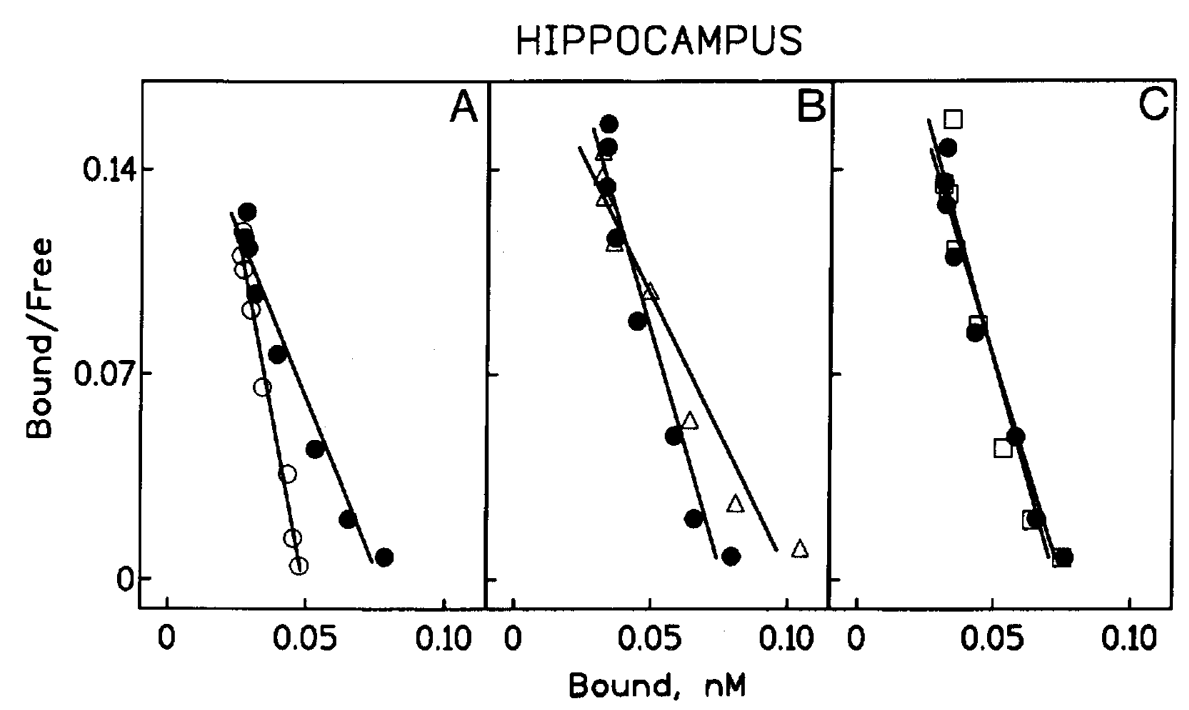


Table 2. Equilibrium Parameters of Somatostatin (SS) Binding to Normal Rat Hippocampal Membranes in the Absence or Presence of $10^{-5} \mathrm{~mol} / \mathrm{L}$ Clonidine and/or Yohimbine Added to the Incubation Medium

\begin{tabular}{lcc}
\hline \multicolumn{1}{c}{ Group } & Bmax & Kd \\
\hline Absence of clonidine & $507 \pm 21$ & $0.43 \pm 0.02$ \\
Presence of clonidine & $530 \pm 21$ & $0.42 \pm 0.02$ \\
Absence of yohimbine & $531 \pm 44$ & $0.33 \pm 0.05$ \\
Presence of yohimbine & $519 \pm 46$ & $0.31 \pm 0.05$ \\
\hline
\end{tabular}

Binding parameters were calculated from Scatchard plots by linear regression (Scatchard 1949). Units for $\mathrm{Kd}$ are $\mathrm{nmol} / \mathrm{L}$ and units for Bmax are femtomoles of SS bound per $\mathrm{mg}$ of protein. The results are represented as the mean \pm SEM of five separate experiments.

Clonidine injection was associated with a decrease in SS binding (Table 1). This decrease is the result of a decrease in the maximal number of SS receptors as revealed by Scatchard plots of the binding data (Table 1 and Figure $1 \mathrm{~A}$ ). This treatment was associated with a decrease in the Kd of SS binding to hippocampal membranes (Table 1). To assess whether clonidine or yohimbine exerted a direct action on SS receptors, $10^{-5} \mathrm{~mol} / \mathrm{L}$ clonidine or yohimbine was included in the incubation medium at the time of the binding assay with membranes from the hippocampus of normal rats. The addition of clonidine or yohimbine to the incubation medium changed neither the number nor the affinity of the SS receptors in the membranes (Table 2 and Figure 2). Pretreatment with yohimbine completely blocked the clonidine-induced changes in the number of SS receptors following clonidine injection (Table 1 and Figure 1C). The administration of yohimbine alone produced a significant increase in ${ }^{125} \mathrm{I}-\mathrm{Tyr}^{11}$-SS binding in hippocampal membranes (Table 1 and Figure 1B).

Because the mechanism of action of SS in the CNS is mediated by $\mathrm{G}$ proteins that are ADP-ribosylated in the presence of PTX, we have studied the PTX substrates in hippocampus after the treatment with cloni-

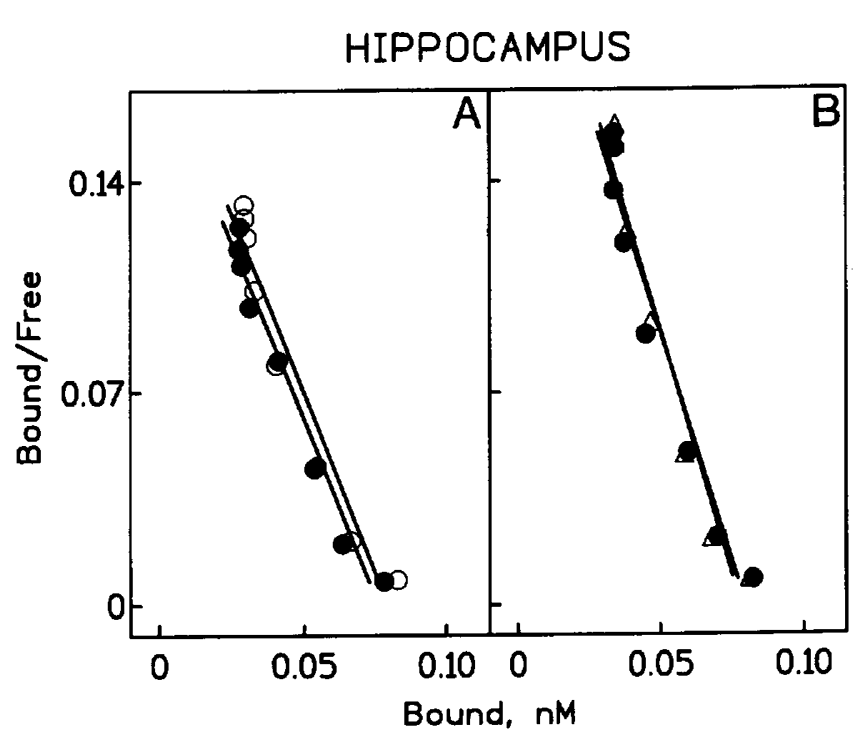

Figure 2. Scatchard plots of the effect of clonidine (A) and/or yohimbine (B) added to the incubation medium on the competitive inhibition by unlabeled somatostatin (SS) of the specific binding of ${ }^{125} \mathrm{I}_{-T y r}{ }^{11}-\mathrm{SS}(250 \mathrm{pmol} / \mathrm{L})$ to normal rat hippocampal membranes $(0.15 \mathrm{mg}$ protein $/ \mathrm{ml})$. Receptor binding was assessed in the absence $(\varphi)$ or presence of $10^{-5} \mathrm{~mol} / \mathrm{L}$ clonidine $(O)$ or yohimbine $(\Delta)$, respectively. Values are expressed as the mean of five replicate experiments. The corresponding equilibrium binding parameters are included in $\mathrm{Ta}$ ble 2.

dine and yohimbine. Pertussis toxin-induced incorporation of ${ }^{32} \mathrm{P}$ in a $41-\mathrm{KDa}$ and $39-\mathrm{KDa} \mathrm{G}$ protein under the conditions studied here (Figure 3 ). Clonidine decreased the PTX-catalyzed ADP-ribosylation of the 41-kDA and 39-kDa G protein alpha subunits, whereas yohimbine had no effect on the PTX-catalyzed ADPribosylation of the alpha subunits.

To study SS-modulated AC activity, hippocampal membranes were incubated with SS $\left(10^{-4} \mathrm{~mol} / \mathrm{L}\right)$, either alone or together with FK $\left(10^{-5} \mathrm{~mol} / \mathrm{L}\right)$, a direct AC activator. As shown in Table 2, no significant differ-

Table 3. Effect of Somatostatin (SS) and Forskolin (FK) on Hippocampal Adenylyl Cyclase (AC) Activity (pmol cAMP $/ \mathrm{min} / \mathrm{mg}$ protein) in Control $(n=15)$, Clonidine- $(n=5)$, Yohimbine- $(n=5)$ and Yohimbine-plus-Clonidine-Treated Rats $(n=5)$

\begin{tabular}{|c|c|c|c|c|c|c|}
\hline & \multicolumn{2}{|c|}{ Clonidine } & \multicolumn{2}{|c|}{ Yohimbine } & \multicolumn{2}{|c|}{$\begin{array}{l}\text { Yohimbine } \\
\text { Plus Clonidine }\end{array}$} \\
\hline & Control & Treated & Control & Treated & Control & Treated \\
\hline $\begin{array}{l}\text { Basal activity } \\
\text { Basal activity }+10^{-4} \mathrm{~mol} / \mathrm{L} \text { SS } \\
\% \text { SS inhibition of basal activity } \\
+10^{-5} \mathrm{~mol} / \mathrm{L} \mathrm{FK} \\
\text { Fold FK stimulation over basal } \\
10^{-5} \mathrm{~mol} / \mathrm{L} \mathrm{FK}+10^{-4} \mathrm{~mol} / \mathrm{L} \mathrm{SS} \\
\% \mathrm{SS} \text { inhibition of FK stimulation }\end{array}$ & $\begin{aligned} 269 & \pm 2 \\
194 & \pm 5 \\
28 & \pm 1 \\
614 & \pm 19 \\
2.3 & \pm 0.1 \\
428 & \pm 16 \\
30 & \pm 1\end{aligned}$ & $\begin{aligned} 261 & \pm 9 \\
219 & \pm 11 \\
16 & \pm 1^{a} \\
632 & \pm 12 \\
2.4 & \pm 0.1 \\
543 & \pm 9 \\
14 & \pm 1^{a}\end{aligned}$ & $\begin{aligned} 225 & \pm 9 \\
162 & \pm 6 \\
28 & \pm 2 \\
571 & \pm 19 \\
2.5 & \pm 1.3 \\
379 & \pm 6 \\
34 & \pm 2\end{aligned}$ & $\begin{aligned} 220 & \pm 11 \\
116 & \pm 5 \\
47 & \pm 5^{b} \\
527 & \pm 28 \\
2.4 & \pm 0.4 \\
261 & \pm 16 \\
50 & \pm 2^{b}\end{aligned}$ & $\begin{aligned} 257 & \pm 7 \\
168 & \pm 11 \\
34 & \pm 3 \\
569 & \pm 20 \\
2.2 & \pm 0.1 \\
356 & \pm 32 \\
37 & \pm 5\end{aligned}$ & $\begin{aligned} 239 & \pm 3 \\
154 & \pm 5 \\
35 & \pm 2 \\
553 & \pm 14 \\
2.3 & \pm 0.1 \\
316 & \pm 17 \\
43 & \pm 2\end{aligned}$ \\
\hline
\end{tabular}

Values represent the mean \pm SEM of the determinations performed. Statistical comparison versus control: ${ }^{a} p<.001,{ }^{b} p<.01$. 
Figure 3. Autoradiograph of $\left[{ }^{32} \mathrm{P}\right] \mathrm{ADP}$ ribosylated brain membrane proteins. Hippocampal membranes $(0.8 \mathrm{mg}$ protein $/ \mathrm{ml})$ from controls, clonidine-, and yohimbinetreated rats were incubated for 30 minutes at $30^{\circ} \mathrm{C}$ in the presence of $\left[{ }^{32} \mathrm{P}\right] \mathrm{NAD}^{+}(30$ $\mathrm{Ci} / \mathrm{mmol})$, with or without pertussis toxin $(16 \mu \mathrm{g} / \mathrm{ml})$. This experiment is representative of six others.
HIPPOCAMPUS

\section{Clonidine Yohimbine}

\author{
Control Treated \\ Control Treated
}
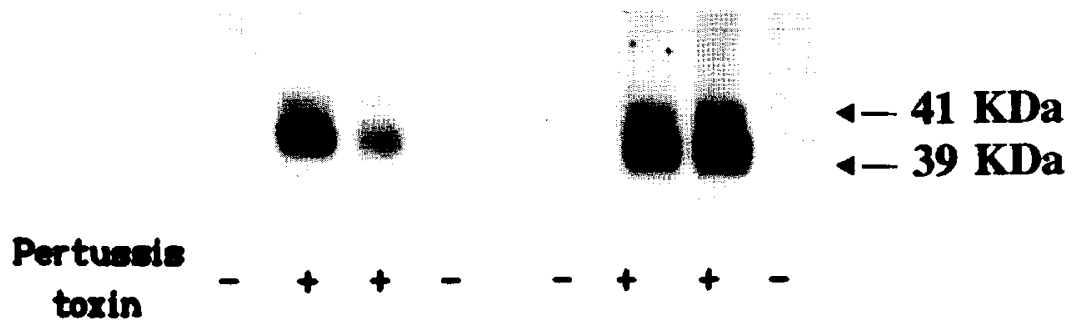

ences were seen for either the basal or the FK-stimulated AC enzyme activities in the control, clonidine, and/or yohimbine groups in hippocampal membranes. In all experimental groups, SS inhibited the basal and the FK-stimulated AC activities. In the clonidine group, however, the capacity of SS to inhibit the basal and FK-stimulated AC activity in the hippocampus was significantly lower than in the control group (Table 2), whereas yohimbine had the opposite effect (Table 2).

\section{DISCUSSION}

The results of these experiments further support the notion that the $\alpha_{2}$-adrenergic system modulates the SS action mechanism in the hippocampus. The SSLI content as well as the binding parameters of SS receptors in the control rats were similar to those previously reported by others (Srikant and Patel 1981; Epelbaum et al. 1982; Reubi 1985; Pitkanen et al. 1986). The Scatchard analysis (Scatchard 1949) of the stoichiometric data suggests the existence of only one type of SS receptor. This finding agrees with some studies in rat brain membranes (Epelbaum et al. 1982; Czernik and Petrack 1983) but differs from other previously reported data (Reubi 1984; Tran et al. 1985). Both Reubi (1984) and Tran et al. (1985) have shown that a newly developed SS analogue, SMS 201-995, is able to identify subtypes of SS receptors in the brain. The photocrosslinking studies of Thermos et al. (1989) suggest that the brain may express at least two molecularly distinct types of SS receptors. Raynor and Reisine (1989) have identified two SS analogues (CGP 23996 and MK 678) that label pharmacologically distinct types of SS receptors in the brain. Recently, five different SS receptor subtypes have been cloned (Raynor et al. 1991; Raynor and Reisine 1992; Bell and Reisine 1993; Bruns et al. 1993; Raynor et al. 1993).

The mechanism by which clonidine and yohimbine cause a modification in SS binding is unknown. How- ever, the changes in ${ }^{125} \mathrm{I}-\mathrm{Tyr}^{11}{ }^{11} \mathrm{SS}$ binding were not a result of a direct effect of clonidine or yohimbine on SS receptors, because no change was detected in tracer binding following incubation of fresh hippocampal membranes with clonidine or yohimbine. In addition, $\alpha_{2}$-adrenoceptors seem to mediate the action of clonidine on the somatostatinergic system, because the changes induced by clonidine in SS binding were prevented by pretreatment with the $\alpha_{2}$-adrenergic blocking agent yohimbine. Nah et al. (1993) have shown that clonidine inhibits the voltage-dependent $\mathrm{Ca}^{2+}$ influx in spinal cord-dorsal root ganglia cocultures, and several electrophysiological studies have shown that $\boldsymbol{\alpha}_{2}$-adrenoceptor agonists decrease $\mathrm{Ca}^{2+}$ channel activity in various peripheral and central neurons (Rosenthal et al. 1988; Sah 1990). The antagonist yohimbine blocks these inhibitory effects of clonidine. Thus, it is conceivable that some of the effects of clonidine or yohimbine on SS binding may be to mobilize a membranebound pool of intracellular $\mathrm{Ca}^{2+}$ that elicits effects in a microenvironment near the plasma membrane resulting in changes in $\mathrm{Ca}^{2+}$ conductance, $\mathrm{K}^{+}$conductance, or both. In this regard, it has been shown that the concentration of calcium in the assay medium regulates both the number of binding sites and the receptor affinity for SS (Susini et al. 1985). On the other hand, exposure to $G$ protein-coupled receptor agonists has been shown to regulate cellular levels of $G$ protein. A mechanism for this type of control likely includes the co-internalization of the receptor and the G protein (Milligan and Green 1991).

Inhibition of rat AC activity by SS was found, which is in agreement with the literature (Nagao et al. 1989; Schettini et al. 1989; Bergström et al. 1991). A relatively high concentration of SS $\left(10^{-4} \mathrm{~mol} / \mathrm{L}\right)$ was required to produce inhibition. The same concentration was used by Schettini et al. (1989), Bergström et al. (1991) and Garlind et al. (1992) in their studies on SS inhibition of human and rat brain AC. Several lines of evidence suggest that the effect of SS is receptor-mediated rather 
than being a nonspecific inhibitory effect. In this respect, the GTP dependence of the inhibitory effect suggests involvement of a $G$ protein in the response. This finding is consistent with binding studies on postmortem human and rat brain tissue that have shown that the binding of SS to its recognition site is affected by GTP in a manner consistent with the involvement of a G protein (Garlind et al. 1992). In addition, Moser and Cramer (1990) have shown that SS acts through $\mathrm{G}$ proteins on dopaminergic $\mathrm{AC}$ in rat brain. Furthermore, Nagao et al. (1989) and Schettini et al. (1989) have shown that SS-reduced cAMP production in the rat brain occurs via a $G$ protein coupled to $A C$. These findings, plus the lack of an inhibitory effect of SS (1 $\mu \mathrm{mol} / \mathrm{L}$ ) on basal $\mathrm{AC}$ activity in primary cultures of mouse embryonic glial cells reported by Chneiweiss et al. (1985) would argue against a nonspecific inhibitory effect of the neuropeptide.

The SS concentration eliciting the maximal inhibition of AC activity was approximately three fold that which was necessary to displace ${ }^{125 I-T y r}{ }^{11}$-SS binding. A possible explanation for this discrepancy may lie in the observation that the PTX-sensitive G proteins can modulate the affinity of SS receptors and/or the coupling to the effector system (AC among others). In this respect, it has been shown by Enjalbert et al. (1983) and by Koch and Schonbrunn (1984) that the mobilization of the G protein by GTP reduces SS receptor affinity for SS in cerebral cortical and in $\mathrm{GH}_{4} \mathrm{C}_{1}$ pituitary cell clones. Indeed, in the presence of GTP necessary to couple the SS receptor to the AC catalyst, the SS receptors may shift from an apparent high-affinity state (observed in binding studies) to an apparent low-affinity state (observed in AC studies). The present results show that the PTX substrate decreases in hippocampus from clonidine-treated rats with respect to control rats. This change could affect the affinity and/or the recruitment of spare receptors and have the consequences observed in these SS binding site experiments.

The ability of SS to inhibit AC was decreased in hippocampal membranes from clonidine-treated rats as compared to controls. However, there did not appear to be any defect in the catalytic unit of $A C$ itself because in hippocampal membranes from either control or clonidine-treated animals, similar levels of activities were noted when this enzyme was stimulated directly by the diterpene FK. Similar heterologous desensitization was observed for $\mathrm{AC}$ response in the hippocampus following dopamine treatment (unpublished results). The mechanism of heterologous desensitization is poorly understood. It has been suggested that heterologous desensitization involves post-receptor modifications, including receptor uncoupling from the $G$ protein transduction mechanism (Klein et al. 1989). Indeed, we found that treatment with clonidine decreased ADPribosylation, suggesting that the decreased ADP- ribosylation is agonist-specific. Furthermore, additional changes, including down-regulation of SS receptors, accompanied receptor desensitization. A similar reduction in PTX-induced ADP-ribosylation was observed following exposure to clonidine in spinal cord-dorsal root ganglion cocultures ( $\mathrm{Nah}$ et al. 1993). In addition, yohimbine blocked the effects of clonidine on PTXcatalyzed ADP-ribosylation in this coculture.

The mechanism by which the $\alpha_{2}$-adrenoceptor agonist clonidine decreases the PTX-catalyzed ADPribosylation of the 41- and 39-kDa G protein subunits is still not clear. However, we cannot rule out the possible involvement of a protein kinase $C$ in the reduction of the ADP-ribosylation by clonidine. Protein kinase $C$ was shown to phosphorylate Gia, thereby suppressing its function in hormonal inhibition of $\mathrm{AC}$ (Katada et al. 1985). In addition, adrenergic agonist treatment may induce alterations in the associationdissociation of the various subunits of the heterotrimeric $G$ protein or in the capacity of the $G$ proteins to interact with the receptor molecules. It is possible that the $\alpha_{2}$-adrenoceptors and the SS receptors are utilizing a common pool of $\mathrm{Gi}$ to inhibit AC activity. The clonidineinduced changes in the organization and/or phosphorylation of the $G$ protein subunits could therefore be responsible for the development of heterologous desensitization in the clonidine-treated animals.

In conclusion, the present data show that hippocampal 41- and 39-kDa G proteins are severely disturbed by the $\alpha_{2}$-adrenergic system and, as a result, the efficiency of the coupling between AC and the corresponding membrane receptors is profoundly affected. As shown in the SS receptor/effector system, the impairment of the final response is further reinforced by the low levels of SS receptors. At present, there is no direct evidence that the regulation of the hippocampal somatostatinergic system by the $\alpha_{2}$-adrenergic system is of physiological significance. However, this mechanism may provide a means by which the environment could modulate the SS action mechanism, and therefore, the sensitivity to SS in a subset of SS-sensitive neurons.

\section{ACKNOWLEDGEMENT}

The authors thank Mr. Luis Monge for assistance in the preparation of the illustrations. This study was supported by a Grant (PB 92-0049) from the Dirección General de Investigación Científica y Técnica.

\section{REFERENCES}

Aguilera G, Parker DS, Catt KJ (1982): Characterization of somatostatin receptors in the rat adrenal glomerulosa zone. Endocrinology 111:1376-1384 
Alburges ME, Bylund DB, Pundt LL, Wamsley JK (1993): $\alpha_{2-}$ Agonist binding sites in brain: [ ${ }^{125} \mathrm{I}$ ]paraiodoclonidine versus $\left[{ }^{3} \mathrm{H}\right]$ paraaminoclonidine. Brain Res Bull 32:97102

Bakst I, Avendano C, Morrison JH, Amaral DG (1986): An experimental analysis of the origins of somatostatin-like immunoreactivity in the dentate gyrus of the rat. J Neurosci 6:1452-1462

Bell GI, Reisine T (1993): Molecular biology of somatostatin receptors. Trends Neurol Sci 16:34-38

Bergström L, Garlind A, Nilsson L, Alafuzoff I, Fowler CJ, Windblad B, Cowburn RF (1991): Regional distribution of somatostatin receptor binding and modulation of adenylyl cyclase activity in Alzheimer's disease brain. J Neurosci Sci 105:225-233

Blaustein JD, Letcher B (1987): Noradrenergic regulation of cytosol strogen receptors in female rat hypothalamus: Possible role of $\alpha_{2}$-noradrenergic receptors. Brain Res 404:51-57

Bokoch GM, Katada T, Northup JK, Hewlett EL, Gilman AG (1983): Identification of the predominant substrate for ADP-ribosylation by islet activating protein. J Biol Chem 258:2072-2075

Bruns Ch, Raulf F, Rohrer L, Kaupmann K, Schüle R, Seuwen K, Hoyer H, Lübbert H (1993): Characterization of SRIF receptor subtypes. $3^{\text {rd }}$ International Pituitary Congress, Marina del Rey, California, Abstr S-52

Bylund DB (1988): Subtypes of $\alpha_{2}$-adrenoceptors: Pharmacological and molecular biological evidence converge. Trends Pharmacol Sci 9:356-361

Chneiweiss J, Glowinski J, Prémont J (1985): Vasoactive intestinal polypeptide receptors linked to an adenylate cyclase, and their relationship with biogenic amine and somatostatin-sensitive adenylate cyclase on central neuronal and glial cells in primary cultures. J Neurochem 44:779-786

Czernik AJ, Petrack V (1983): Somatostatin receptor binding in rat cerebral cortex. Characterization using a nonreducible somatostatin analog. J Biol Chem 285:5525-5530

Enjalbert A, Rasolon-Janahary R, Moyse E, Kordon C, Epelbaum J (1983): Guanine nucleotide sensitivity of [ $\left.{ }^{125} \mathrm{I}\right]-$ iodo-N-Tyr-somatostatin binding in rat adenohypophysis and cerebral cortex. Endocrinology 113:822-824

Epelbaum J (1986): Somatostatin in the central nervous system: Physiology and pathological modifications. Prog Neurobiol 27:63-100

Epelbaum J, Tapia-Arancibia L, Kordon C, Enjalbert A (1982): Characterization, regional distribution and subcellular distribution of ${ }^{125} \mathrm{I}_{-} \mathrm{Tyr}^{1}$-somatostatin binding sites in rat brain. J Neurochem 38:1515-1523

Epelbaum J, Bluet-Pajot MT, Llorens-Cortes C, Kordon C, Mounier F, Senut MC, Videau C (1990): ${ }^{125} \mathrm{I}-\left[\mathrm{Tyr}^{0}\right.$, Trp ${ }^{8}$ ]somatostatin-14 binding sites in the locus coeruleus of the rat are located on both ascending and descending projecting noradrenergic cells. Peptides 11:21-27

Garlind A, Fowler CJ, Alafuzoff I, Winblad B, Cowburn RF (1992): Neurotransmitter-mediated inhibition of postmortem human brain adenylyl cyclase. J Neural Transm 87:113-124

Gilman AG (1970): A protein binding assay for adenosine 3', 5'-cyclic monophosphate. Proc Natl Acad Sci USA 67:305-312

Glowinski ], Iversen LL (1966): Regional studies of catecholamines in the rat brain. I. The disposition of $\left[{ }^{3} \mathrm{H}\right]$ norepinephrine, $\left[{ }^{3} \mathrm{H}\right]$ dopamine and $\left[{ }^{3} \mathrm{H}\right] \mathrm{DOPA}$ in various regions of the brain. J Neurochem 13:655-669

Greenwood FC, Hunter WM, Glober JS (1963): The preparation of ${ }^{131}$ I-labelled human growth hormone of high specific radioactivity. Biochem J 89:114-123

Guijarro LG, Couvineau A, Rodriguez-Pena MS, Juarranz MG, Rodríguez-Henche N, Arilla E, Laburthe M, Prieto JC (1992): Vasoactive intestinal peptide receptors in rat liver after partial hepatectomy. Biochem J 285:515-520

Houslay MD, Metcalfe JC, Warren GB, Hesketh TR, Smith GA (1976): The glucagon receptor of rat liver plasma membrane can couple to adenylate cyclase without activating it. Biochim Biophys Acta 436:489-494

Jackisch R, Geppert M, Iles P (1986): Characterization of opioid receptors modulating noradrenaline release in the hippocampus of the rabbit. J Neurochem 46:1802-1810

Jöels M, Madamba SG, Moore SD, Morrison JH, Siggins GR (1990): Somatostatin immunohistochemistry of hippocampal slices with Lucifer yellow-stained pyramidal neurons responding to somatostatin. Regul Pept 28: 215-221

Katada T, Gilman AG, Watanabe Y, Bauer S, Jakobs KH (1985): Protein kinase $C$ phosphorylates the inhibitory guanine-nucleotide binding regulatory component and apparently suppresses its function in hormonal inhibition of adenylate cyclase. Eur J Biochem 151:431-437

Klein WL, Sullivan J, Skorupa A, Aguilar JS (1989): Plasticity of neuronal receptors. FASEB J 3:2132-2140

Koch BD, Schonbrunn A (1984): The somatostatin receptor is directly coupled to adenylate cyclase in $\mathrm{GH}_{4} \mathrm{C}_{1}$ pituitary cell membranes. Endocrinology 114:1784-1790

Krantic S, Martel JC, Weismann D, Pujol JF, Quirion R(1990): Quantitative autoradiographic study of somatostatin receptors heterogeneity in the rat extrahypothalamic brain. Neuroscience 39:127-137

Laburthe M, Breant B, Rouyer-Fessard C (1984): Molecular identification of receptors for vasoactive intestinal peptide in rat intestinal epithelium by covalent cross-linking. Evidence for two classes of binding sites with different structural and functional properties. Eur J Biochem 139:181-187

Laemmli UK (1970): Cleavage of structural proteins during the assembly of the head of bacteriophage $T_{4}$. Nature 227:680-685

Levitt P, Moore RY (1978): Noradrenaline neuron innervation of the neocortex in the rat. Brain Res 139:219-231

López-Sañudo S, Arilla E (1992): Desmethylimipramine pretreatment prevents 6-hydroxydopamine induced somatostatin receptor reduction in the rat hippocampus. Regul Pept 41:227-236

Lowry OH, Rosenbrough NJ, Farr AL, Randall RJ (1951): Protein measurement with Folin phenol reagent. J Biol Chem 193:265-275

Milligan G, Green A (1991): Agonist control of G-protein levels. Trends Pharmacol Sci 12:207-209 
Milner TA, Bacon CE (1989): Ultrastructural localization of tyrosine hydroxylase-like immunoreactivity in the rat hippocampal formation. J Comp Neurol 281:479-495

Moore RY, Bloom FE (1979): Central catecholaminergic neuron systems: Anatomy and physiology of the norepinephrine systems. Annu Rev Neurosci 2:113-504

Moser A, Cramer H (1990): Somatostatin acts through G proteins on dopaminergic adenylate cyclase in the caudateputamen of the rat. Neurochem Res 15:1085-1088

Munson PJ, Rodbard D (1980): LIGAND: A versatile computerized approach for characterization of ligand binding systems. Anal Biochem 107:220-239

Murray-Whelan R, Schlegel W (1992): Brain somatostatin receptor- $G$ protein interaction. J Biol Chem 267:2960-2965

Nagao M, Sakamoto C, Matozaki T, Nishizaki H, Konda Y, Nakano O, Baba S (1989): Coupling of inhibitory GTP binding protein to somatostatin receptors on rat cerebrocortical membranes. Folia Endocrinol Jpn 65:1357-1366

Nah SY, Attali B, Vogel Z (1993): Heterologus desensitization and reduced $G$ protein ADP-ribosylation following exposure to $\alpha_{2}$-adrenoceptor and muscarinic receptor agonists. Eur J Pharmacol 244:67-75

Palacios JM, Reubi JC, Maurer R (1986): Somatostatin receptors in rat hippocampus: Localization to intrinsic neurons. Neurosci Lett 67:169-174

Pang K, Rose GM (1987): Differential effects of norepinephrine on hippocampal complex-spike and $\theta$-neurons. Brain Res 425:146-158

Patel JC, Reichlin S (1978): Somatostatin in hypothalamus, extrahypothalamic brain and peripheral tissues of the rat. Endocrinology 102:523-531

Penman E, Wass JAH, Lund A, Lowry PJ, Stewart J, Dawson AM, Besser GM, Rees LH (1979): Development and validation of a specific radioimmunoassay for somatostatin in human plasma. Ann Clin Biochem 16:15-25

Pitkanen A, Sirvio J, Jolkkonen J, Reikkinen P (1986): Somatostatin-like immunoreactivity and somatostatin receptor binding in rat brain before and after pentylenetetrazol induced convulsion. Neuropeptides 7:63-71

Raynor K, Reisine T (1989): Analogs of somatostatin selectively label distinct subtypes of somatostatin receptors in rat brain. J Pharmacol Exp Ther 251:510-517

Raynor K, Reisine T (1992): Differential coupling of somatostatin receptors to adenylyl cyclase in the rat striatum vs. the pituitary and other regions of the rat brain. J Pharmacol Exp Ther 260:841-848

Raynor K, Wang HL, Dichter M, Reisine T (1991): Subtypes of somatostatin receptors couple to multiple cellular effector systems. Mol Pharmacol 40:248-253

Raynor K, O'Carroll AM, Kong H, Yasuda K, Mahan LC, Bell GI, Reisine T (1993): Characterization of cloned somatostatin receptors SSTR4 and SSTR5. Mol Pharmacol 44:385-392

Reichlin S (1983): Somatostatin. N Engl J Med 309:1495-1556

Reubi JC, Perrin MH, Rivier JE, Vale V (1981): High affinity binding sites for the somatostatin-28 annalogue in rat brain. Life Sci 28:2191-2198

Reubi JC (1984): Evidence for two somatostatin-14 receptor types in rat brain cortex. Neurosci Lett 49:259-263

Reubi JC (1985): New specific radioligand for one subpopulation of brain somatostatin receptors. Life Sci 36:18291836

Rezek M, Havlicek V, Leybin L, Labella FS, Friesen H (1977): Opiate-like naloxone-reversible actions of somatostatin given intracerebrally. Can J Physiol Pharmacol 56:227-231

Rosenthal W, Hescheler J, Trautwein W, Schulz G (1988): Control of voltage-dependent $\mathrm{Ca}^{2+}$ channels by $\mathrm{G}$ protein-coupled receptors. FASEB J 2:2784-2790

Sah DWJ (1990): Neurotransmitter modulation of calcium current in rat spinal cord neurons. J Neurosci 12:207-209

Sakanaka M, Magari S, Inoue N (1990): Somatostatin colocalizes with tyrosine hydroxylase in the nerve cells of discrete hypothalamic regions in rats. Brain Res 516:313-317

Scatchard G (1949): The attractions of proteins for small molecules and ions. Ann NY Acad Sci 51:660-671

Schettini G, Florio T, Meucci O, Landolfi E, Grimaldi M, Ventra C, Marino A (1989): Somatostatin inhibition of adenylate cyclase activity in different brain areas. Brain Res 492:65-71

Schweitzer P, Madamba S, Champagnat J, Siggins GR (1993): Somatostatin inhibition of hippocampal CA1 pyramidal neurons: Mediation by arachidonic acid and its metabolites. J Neurosci 13:2033-2049

Seamon KB, Daly JW (1986): Forskolin: Its biological and chemical properties. In Greengard P, (ed), Advances in Cyclic Nucleotide and Protein Phosphorylation Research, Raven Press, New York, Vol 20, pp 1-150

Seroogy K, Hökfelt T, Buchan A, Browns JC, Terenius L, Norman AW, Goldstein M (1989): Somatostatin-like immunoreactivity in rat main olfactory bulb: Extent of coexistence with neuropeptide $Y-$, tyrosine hydroxylase- and vitamin D-dependent calcium binding protein-like immunoreactivities. Brain Res 496:389-396

Srikant CB, Patel YC (1981): Somatostatin receptors: Identification and characterization in rat brain membranes. Proc Natl Acad Sci USA 78:3930-3934

Susini C, Esteve JP, Vaysse N, Ribet A (1985): Calciumdependence of somatostatin binding to receptors. Peptides 6:831-833

Thermos K, He HT, Wang HL, Margolis N, Reisine T (1989): Biochemical properties of brain somatostatin receptors. Neuroscience 31:131-141

Tran V, Beal F, Martin J (1985): Two types of somatostatin receptors differentiated by cyclic somatostatin analogs. Science 228:492-495

Wamsley JK, Alburges ME, Hunt MAE, Bylund DB (1992): Differential localization of $\alpha_{2}$-adrenergic receptor subtypes in brain. Pharmacol Biochem Behav 41:267-273

Watson TWJ, Pittman QJ (1988): Pharmacological evidence that somatostatin activates the M-current in hippocampal pyramidal neurons. Neurosci Let 91:172-176 